\title{
Performance of Stock and Treasury Bills under Inflation and Floating: Evidence from Egypt
}

\author{
Osama Wagdi ${ }^{1}$, Yasmin Tarek $^{1} \&$ Nihad Edres ${ }^{1}$ \\ ${ }^{1}$ Faculty of Management, Modern University for Technology and Information (MTI), Cairo, Egypt \\ Correspondence: Osama Wagdi, Financial Institutions Department, Modern University for Technology and \\ Information, El-hadaba El-Wosta, Mokatam, 5th district, Cairo, Egypt. Tel: 201-224-886-966. E-mail: \\ osamawagdi_ta@yahoo.com
}

Received: March 30, 2018

Accepted: April 22, 2018

Online Published: May 20, 2018

doi:10.5539/ijef.v10n6p160

URL: https://doi.org/10.5539/ijef.v10n6p160

\begin{abstract}
The aim of this study is comparing the performance of common stock \& treasury bills, according to the central bank of Egypt and their monetary policy during the time period between "1994-2017", using descriptive \& inferential statistical methods. The Study concluded that there is a strong positive relationship between inflation rate \& returns of Egyptian treasury bills, as the same relation as with floating Egyptian pound.

in addition, the study found the impact of Inflation and Floating on the return of Egyptian T-bills, but don't found this impact on the return of Egyptian common stock. Finally, the study founds the same average return but a different at variances of this return \& the Coefficient of variation.
\end{abstract}

Keywords: financial market, financial instrument, stock, treasury bills, inflation, floating, interest rate, monetary policy, Egypt, EGX

\section{Introduction}

\subsection{Introduce the Problem}

Financial instruments can be classified according to the relationship between return and risk. Government securities are the least risk \& return when compared with a common stock; the structure of financial assets return varies according to the financial instrument type; Egypt; in 2017 treasury bills return increased to abnormal levels, which could be explained by the influence of market imperfections on security pricing.

The structure of the return of financial assets varies between these instruments. The return on the Treasuries has reached abnormal returns; this can be explained according to the influence of market imperfections on security pricing has long been recognized. Market performance, in particular, has attracted a lot of attention from traders, regulators, exchange officials as well as academics.

Since 2008; the financial institutions have shifted their strategies to overweight their investments with local debt instruments (Individuals are not allowed to trade directly on government debt instruments). Since the floating of foreign exchange (11/2016), Egypt witnessed foreign inflows of government debt instruments, due to the increase in local interest rates by the Central Bank of Egypt.

\subsection{Explore Importance of the Problem}

There are a lot of economic reforms and changes in the Egyptian economy. This has led to a change in the structure of performance of financial instruments (structure of return \& structure of risk). Is this only in the short term? Or it is also in the long term. So answers are needed for the following questions:

- Is there an impact of Inflation rate and floating exchange rate on Egyptian T-bills performance?

- Is there an impact of Inflation rate and floating exchange rate on Egyptian common performance?

- What is the difference between common stocks and T-bills performance?

\subsection{Literature Review}

There are previous studies related to the relation between stock and treasury bills performance \& inflation rate, interest rate and floating exchange rate, the first is Fama (1981) the second is Jacoby et al. (2000) provides theoretical arguments to show how inflation and treasury bills impact valuation of instruments. There are many 
studies on this subject as well.

Table 1. Literature review

\begin{tabular}{|c|c|c|c|}
\hline Author & $\begin{array}{l}\text { Study Period } \\
\& \text { Population }\end{array}$ & Variables & Conclusion \\
\hline $\begin{array}{l}\text { Fabio C. Bagliano \& } \\
\text { Andrea Beltariti } \\
\qquad(1997)\end{array}$ & $\begin{array}{l}\text { 1963-1995 } \\
\text { Italy }\end{array}$ & $\begin{array}{l}\text { stock market } \\
\text { returns \& the } \\
\text { nominal interest } \\
\text { rate }\end{array}$ & $\begin{array}{l}\text { The study concluded that there is a strong negative relation between real stock } \\
\text { index level and the inflation rate. }\end{array}$ \\
\hline $\begin{array}{l}\text { Khalid Nadeem Khan } \\
\qquad \text { (2004) }\end{array}$ & $\begin{array}{l}\text { 1980-1999 } \\
\text { Pakistan }\end{array}$ & $\begin{array}{l}\text { The rate of } \\
\text { inflation \& stock } \\
\text { return }\end{array}$ & $\begin{array}{l}\text { The study concluded that real rate of return on financial assets was decreased } \\
\text { by the inflation strengthens frictions in the stock market which lead to a } \\
\text { decrease in trading and capitalization in the stock market. }\end{array}$ \\
\hline $\begin{array}{l}\text { Muhammad Shahbaz } \\
\text { Akmal (2007) }\end{array}$ & $\begin{array}{l}\text { 1971-2006 } \\
\text { Pakistan }\end{array}$ & $\begin{array}{l}\text { Inflation \& stock } \\
\text { market prices }\end{array}$ & $\begin{array}{l}\text { The study concluded that the under-ground economy (black economy) } \\
\text { promotes higher prices for stocks on long run and on short run while the stock } \\
\text { returns are hedges against inflation on long run only. }\end{array}$ \\
\hline $\begin{array}{l}\text { Ang, Andrew, Marie } \\
\text { Brière, and Ombretta } \\
\quad \text { Signori (2012) }\end{array}$ & $\begin{array}{l}\text { 1994-2010 } \\
\text { USA }\end{array}$ & $\begin{array}{l}\text { Inflation \& stock } \\
\text { market return }\end{array}$ & $\begin{array}{l}\text { The study concluded a considerable time variation among stock inflation betas, } \\
\text { which leads to a difficult construction of portfolios from stocks that are strong } \\
\text { out-of-sample inflation hedges. } \\
\text { This result holds for sector portfolios, portfolios constructed on past-inflation } \\
\text { betas, and portfolios constructed from high-dividend-paying stocks. }\end{array}$ \\
\hline $\begin{array}{l}\text { Samuel Antwi } \\
\text { Ebenezer- Fiifi Emire } \\
\text { Atta Mills -Professor } \\
\text { Xicang Zhao (2012) } \\
\end{array}$ & $\begin{array}{c}\text { 1990-2010 } \\
\text { Ghana }\end{array}$ & $\begin{array}{l}\text { Treasury Bill and } \\
\text { the Capital } \\
\text { Market } \\
\text { Instruments } \\
\end{array}$ & $\begin{array}{l}\text { The study proved that the returns on treasury bills are lower than returns on } \\
\text { equities on the long run only. It also found that the average returns on listed } \\
\text { equities and treasury bills are higher than the average rate of inflation. }\end{array}$ \\
\hline $\begin{array}{l}\text { Aviral Kumar Tiwari, } \\
\text { Arif Billah Dar, Niyati } \\
\text { Bhanja, MohamedAro } \\
\& \text { uri Frédéric Teulon } \\
\text { (2015) }\end{array}$ & $\begin{array}{l}\text { 1961-2012 } \\
\text { Pakistan }\end{array}$ & $\begin{array}{l}\text { Wholesale Price } \\
\text { Index (WPI), } \\
\text { Consumer Price } \\
\text { Index (CPI) and } \\
\text { stock prices }\end{array}$ & $\begin{array}{l}\text { The study concluded that on the long run the stock market of Pakistan could } \\
\text { act as hedge against inflation, in case that inflation does not erode stock returns } \\
\text { values. }\end{array}$ \\
\hline $\begin{array}{l}\text { Halit Aktürk } \\
\qquad(2016)\end{array}$ & $\begin{array}{c}\text { 1986-2013 } \\
\text { Turkey }\end{array}$ & $\begin{array}{l}\text { Nominal stock } \\
\text { returns and } \\
\text { inflationary } \\
\text { expectations }\end{array}$ & $\begin{array}{l}\text { The study concluded that the stocks of manufacturing industry firms provide a } \\
\text { hedge higher by } 15 \% \text { than that of service industry firms. And stock returns did } \\
\text { not provide a good hedge for ex-post realized expected inflation but provide a } \\
\text { good hedge against ex-ante inflationary expectations. }\end{array}$ \\
\hline $\begin{array}{l}\text { Bampinas, Georgios, } \\
\quad \& \text { Theodore } \\
\text { Panagiotidis (2016) }\end{array}$ & $\begin{array}{l}\text { 1993-2012 } \\
\text { USA }\end{array}$ & $\begin{array}{l}\text { stock returns and } \\
\qquad \mathrm{CPI}\end{array}$ & $\begin{array}{l}\text { The study concluded that the companies average inflation hedging ability } \\
\text { declined steadily over the past ten years, while the number of firms that hedge } \\
\text { inflation has decreased considerably }\end{array}$ \\
\hline $\begin{array}{l}\text { Iddrisu Suhaibu, } \\
\text { Simon K. Harvey \& } \\
\text { Mohammed Amidu } \\
\text { (2017) }\end{array}$ & $\begin{array}{l}1997-2013 \\
12 \text { African } \\
\text { countries }\end{array}$ & $\begin{array}{l}\text { GDP growth, } \\
\text { inflation, } \\
\text { monetary policy } \\
\text { and stock market }\end{array}$ & $\begin{array}{l}\text { The study concluded that In the long term, the study proved a bidirectional } \\
\text { relation between monetary policy tools and stock market shocks in Africa. } \\
\text { While stock market responds positively to interest rate shock, interest rate } \\
\text { responds negatively to a negative stock market shock. }\end{array}$ \\
\hline $\begin{array}{l}\text { Hendrik } \\
\text { Bessembinder } \\
\quad(2017)\end{array}$ & $\begin{array}{c}\text { 1926-2016 } \\
\text { USA }\end{array}$ & $\begin{array}{l}\text { Performance of } \\
\text { stocks, treasury } \\
\text { bills and market } \\
\text { return. }\end{array}$ & $\begin{array}{l}\text { The study concluded that more than four out of every seven common stocks } \\
\text { that have appeared in the CRSP database since } 1926 \text { have lifetime } \\
\text { buy-and-hold returns, inclusive of reinvested dividends, less than those on } \\
\text { one-month Treasuries. In term of life time the gain of dollar wealth in the US } \\
\text { stock market since } 1926 \text { is regarded being caused by the best-performing four } \\
\text { percent of listed companies. }\end{array}$ \\
\hline $\begin{array}{l}\text { Angelos Kanas } \\
\text { \& Sotirios Karkalakos } \\
\text { (2017) }\end{array}$ & $\begin{array}{c}1977-2011 \\
\text { USA \& UK }\end{array}$ & $\begin{array}{l}\text { equity flows } \\
\text { and } \\
\text { exchange rate }\end{array}$ & $\begin{array}{l}\text { The study found that the UK investors engaged in a "trend chasing" which } \\
\text { means a positive feedback trading to rebalance their portfolios, also the study } \\
\text { found that there is a volatility spillovers across exchange rate returns, equity } \\
\text { flows and equity returns. Finally the study found that equity returns are } \\
\text { affected dynamically by net flows which explain the trading rule that portfolios } \\
\text { are dynamically adjusted over a short - run affecting variation in stock returns. }\end{array}$ \\
\hline $\begin{array}{l}\text { Otieno, Donald A., } \\
\text { Rose W. Ngugi, and } \\
\text { Peter W. Muriu } \\
\text { (2018) }\end{array}$ & $\begin{array}{c}\text { 1993-2015 } \\
\text { Kenya }\end{array}$ & $\begin{array}{l}\text { inflation rate and } \\
\text { stock market } \\
\text { returns }\end{array}$ & $\begin{array}{l}\text { The study found that there are non-integer orders of integration in the stock } \\
\text { market returns, the month-on-month inflation rate and the year-on-year } \\
\text { inflation rate. This is not compatible with the nonstationary/stationary results } \\
\text { often obtained from the conventional unit root tests and indicates that any } \\
\text { shocks to the variables will continue steadfastly but usually disappear. }\end{array}$ \\
\hline
\end{tabular}




\begin{tabular}{|c|c|c|c|}
\hline $\begin{array}{c}\text { Li, X., Su, C. W., } \\
\text { Chang, H. L., \& Ma, } \\
\text { J. (2018) }\end{array}$ & $\begin{array}{c}\text { 2003-2015 } \\
\text { China }\end{array}$ & $\begin{array}{l}\text { international } \\
\text { capital } \\
\text { movements } \\
\text { (SICM), The } \\
\text { exchange rate, } \\
\text { short-term and } \\
\text { stock prices (SP) }\end{array}$ & $\begin{array}{l}\text { The study used the wavelet analysis to examine the effect of short-run } \\
\text { international capital movements (SICM) on the interaction mechanism between } \\
\text { the stock prices (SP) and the exchange rate. The bilateral co-movements } \\
\text { between these variables are time-dependent and not compatible in some } \\
\text { periods, and the flow of SICM is not enough to clarify the difference between } \\
\text { the results determined by examining exchange rate nexus alone and SP and } \\
\text { then examining it by considering SICM as a control variable so designating a } \\
\text { limited mediating effect of SICM. But SICM still cannot be disregarded with } \\
\text { the process of Renminbi internationalization and capital account liberalization. }\end{array}$ \\
\hline
\end{tabular}

Through Literature review, the study finds the following:

1) There is an impact of inflation on stock returns; both in global and emerging markets; but this relationship may vary between the short and the long term.

2) There is a relationship between inflation, Treasury and the real returns of Treasury bill \&stock returns.

3) There are many investors find in stocks as a hedge against the risks of inflation.

4) There is a correlation between Inflation and exchange rate.

5) Inflation and exchange rates cannot be analysed away from the economic policies implemented by the central bank and the financial authorities.

6) The exchange rate and inflation rates are one of the determinants of investment in equity and government debt instruments.

7) There is an impact of exchange rates on foreign investment flows to financial markets, especially when floating

\subsection{State Hypotheses}

According to the study problem \& Literature Review, the Study Hypotheses can be show as follows:

1) There a significant impact of Inflation and Floating on return of Egyptian T-bills performance.

2) There a significant impact of Inflation and Floating on return of Egyptian common stock performance.

3) There a significant difference between the performance of common stocks and T-bills according.

\subsection{Study Objective}

The main objective of this study is to provide an analysis \& comparison between the performance of common stocks and T-bills \& conclude the impact of inflation rate and exchange rate floating on their Performance.

\section{Method}

Any investment decision is a relationship between risk and return, however, there are some models have analyzed this relationship such as the Capital Market Line [CML] (Markowitz, 1952), the Capital Asset Pricing Model [CAPM] (Sharpe, 1964) (Lintner, 1965) (Mossin, 1966) \& the Arbitrage Pricing Theory [APT] (Ross, 1976).

These models are closely related to portfolio theory and provide an application on portfolio risk management, fund performance measurement, security valuation, etc. (Zabarankin et al., 2014) (Perold, 2004); but examination of these models is focused in USA \& Europe (UK, France \& Germany) but scarce in the Middle East stock market.

The study; According to the arbitrage pricing theory (APT), the trader at Egyptian exchange (EGX) has many opportunities trading when the monetary authorities (Central Bank of Egypt) are used interest rates and foreign exchange rates to implement the development plans in Egypt.

\subsection{Data and Methodology}

To achieve the objectives of the research and testing hypotheses the study uses the methodology of regression analysis and a cross section analysis using the data from Egypt. The study includes two types' financial instruments, its Treasury bill (T-Bill) \& common stock over the period from 1994 to 2017.

\subsection{Monetary Policies in Egypt}

Monetary Authority aims to achieve price stability in a way consistent with the national objectives of stimulating economic growth, facing inflation and unemployment. 
Central Bank of Egypt applied an indirect Monetary management, along with the reserve requirement ratio which was remained unchanged at $14 \%$, and the discount rate which was lowered from $11 \%$ to $10 \%$ per annum through the periods " $2002,2003 \& 2004$ " to reduce interest rates at banks and, in turn, encourage investment and boost economic growth.

2005 , overnight deposit and lending rates were set at 9.5\% and 12.5\%, respectively, 2008-2009 these rates were raised to $11.5 \%$ and $13.5 \%$ respectively.

2010, overnight deposit and lending rates and discount rate were set at $8.25 \%, 9.75 \%$ and $8.50 \%$ per annum, in order, these rates were kept applicable till 2011; then these rates were raised \& remained unchanged at $9.25 \%$, $10.25 \%$ \& $9.5 \%$ respectively till 2014.

2017 , overnight deposit and lending rates were raised to $18.75 \%$ from $11.75 \%$ in 2016 \& to $19.75 \%$ in 2017 from $12.75 \%$ in 2016 , respectively.

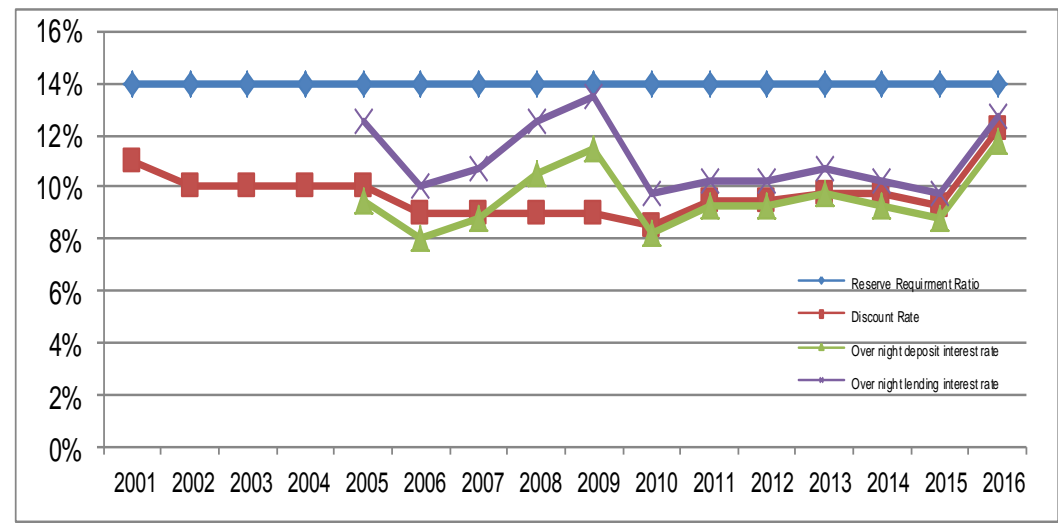

Figure 1. The main indicators of monetary policy in Egypt during (2001-2016)

Source: Central bank of Egypt Annual report (2001-2016).

\subsection{Exchange Rate Policy in Egypt}

During the period of sixties till 2001, exchange rate for Egyptian pound had been relatively stable relative to USD" pegged exchange rate regime", except for periods when devaluations occurred to reflect a more competitive value for the exchange rate; so monetary authority tried to stabilize Egyptian pound exchange rate by adopting: "fixed adjustable peg, managed floating, and crawling peg " exchange rate regimes.

Starting from the sixties till 1990 Exchange rate regime was "Fixed but Adjustable Peg", when Egyptian authority kept the rate of Egyptian Pound to USD fixed, then it was devalued from 1.1 EGP per $1 \$$ to 2 EGP per USD in July 1990.

With the beginning of applying Economic Reform Program "In February 1991" monetary authority changed its exchange rate policy to a "managed floating"; as a result of this new regime Egyptian Pound devalued from 2 EGP to 3.4 EGP per USD, on average between February 1991 and December 2000.

Over the period of January 2001 to December 2002, the exchange rate of Egyptian Pound was devalued following "Crawling Peg ", when central bank set exchange rate at 3.85 EGP per 1 , then it devalued Egyptian Pound exchange rate to 4.14 EGP per USD. Then as a result of the 9/11 terrorist act against USA and its consequences on Egyptian economy, which was reflected on losses in tourism sector, FDI \& Suez Canal revenues, Central Bank of Egypt devalued Egyptian Pound one more time in January 2002 to reach 4.5 EGP per USD. Central Bank of Egypt kept this rate till its announcement of adopting" Free Floating ER Regime" in January 2003, when Egyptian Pound depreciated from 4.5 EGP in 2003 to be 6.3 EGP per USD in 2004.

In 2011 as a result of political and social instability which had great impacts on Egyptian economy, exchange rate depreciated by "5.17\%" from 5.8 EGP in January 2011 to 6.1 LE per USD in November 2012, because of the huge decline in reserves during that period.

So it could be concluded that exchange rate of Egyptian pound was managed with various degree of flexibility against the US dollar till 2016 when the Central Bank of Egypt unexpectedly announced the free-floating of the pound on the $3^{\text {rd }}$ of November, in an attempt to alleviate an ailing economy struck by a severe shortage of U.S. 
Dollars \& international reserves and a widening margin between black and official exchange rate markets, local currency depreciated to 13 EGP per USD, which represented a weakening of $46.3 \%$ from 8.88 EGP per USD previously.

The movement towards a free floating regime was a necessary condition for the IMF board to consider granting Egypt a loan of 12.0 billion USD, which would help plug the severe fiscal deficit that is set to run that year.

IMF officials praised the step taken towards normalizing the currency, stating that it will improve Egypt's external competitiveness and support exports and tourism.

\subsection{Descriptive Statistical Methods}

\subsubsection{Performance of Egyptian Exchange (According to EFG Hermes Index)}

Egyptian Exchange is one of the oldest stock markets established in the Middle East. The Egyptian Exchange traces its origins to 1883 when the Alexandria Stock Exchange was established, followed by the Cairo Stock Exchangein1903; In the early nineties, Egypt began the application of the economic reform program, which included the activation of the role of the private sector, which revived the Egyptian capital market again , especially with the development of the capital market No. 95 Act , 1992, and in 1994 two exchanges transformed from a trading manual to use an electronic system for trading. In the second half of the nineties the government began the privatization program, which was put up a large number of companies through the stock exchange, which contributed to the recovery of the market dramatically, attracting a large segment of investors to the Egyptian market, where that period represents the real start for the prosperity of the Egyptian Stock Exchange again in the Covenant the talk.

Major index of Egyptian exchange (EGX) is EGX 30 index, but EFG Hermes Index is an older Major index \& more diversification of Egyptian exchange (EGX).

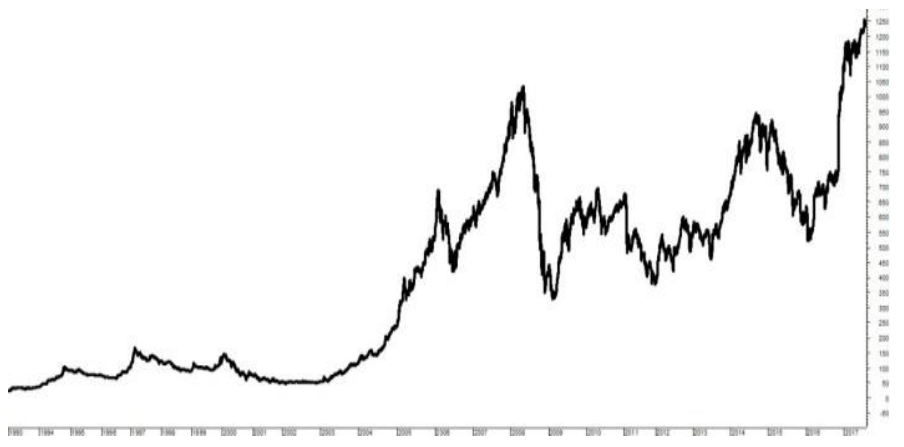

Figure 2. EFG Hermes index

Source: EFG Hermes.

EFG Hermes Index is older Egyptian Exchange Indexes; during the considered time period (1994-2017), the index reached its peaks in 10/1994, 2/1997, 2/2000, 1/2006, 4/2008, 4/2010, 9/2014 \& 12/2017 but its bottoms in 7/1996, 12/1998, 1/2002, 6/2006, 2/2009, 12/2011 \& 1/2016, so Egyptian Exchange has a level of volatility.

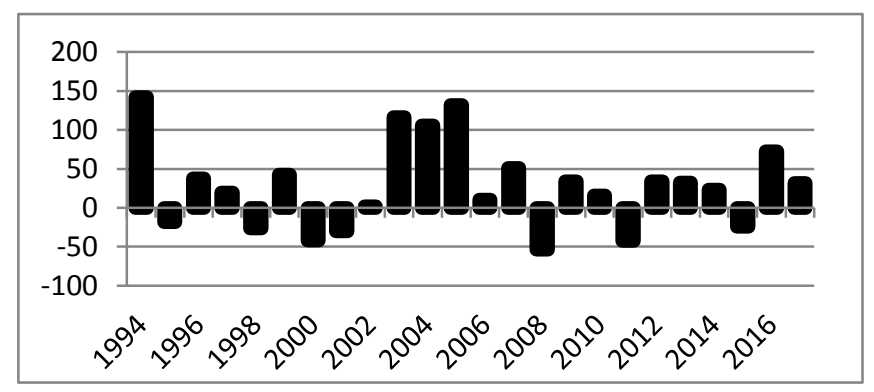

Figure 3. The performance of Egyptian exchange according to EFG Hermes index

Source: The authors according to EFG Hermes data.

From Figure 3, in 1994, 2003, 2004 \& 2005 the return of Egyptian Exchange according to EFG Hermes Index more than $100 \%$. 
Table 2. Descriptive statistics of EFG Hermes index

\begin{tabular}{lllllllll}
\hline Stock Return & Minimum & Maximum & Mean & Std. Deviation & \multicolumn{2}{l}{ Skewness } & & \multicolumn{2}{c}{ Kurtosis } \\
According To Efg & Statistic & Statistic & Statistic & Statistic & Statistic & Std. Error & Statistic & Std. Error \\
\cline { 2 - 9 } Hermes Index & -53.9366 & 141.9474 & 27.75841 & 54.99758 & 0.581507 & 0.472261 & -0.25867 & 0.917777 \\
\hline
\end{tabular}

Source: Statistical Package for the Social Sciences output.

From Table 2, the mean return of EFG Hermes Index, it is $27.75 \%$ but the stander deviation is 54.9976 that show a high level of risk for Egyptian Exchange.

\subsubsection{Performance of Egyptian T-Bills (91 days)}

Egyptian Government Treasury Bills is a Short-term security one year and less, The Central Bank of Egypt (CBE) issued treasury bills (T-bills) behalf of the Ministry of Finance (MOF). EGP Treasury bill Type (days) are 91, $182,273 \& 364$ days.

EGP Treasury bills commonly pay no explicit interest but are sold at a discount, their yield being the difference between the purchase price and the Face-value (also called redemption value). T-bills are very popular with institutional investors because, being backed by the government's full faith and credit, they come closest to a free risk.

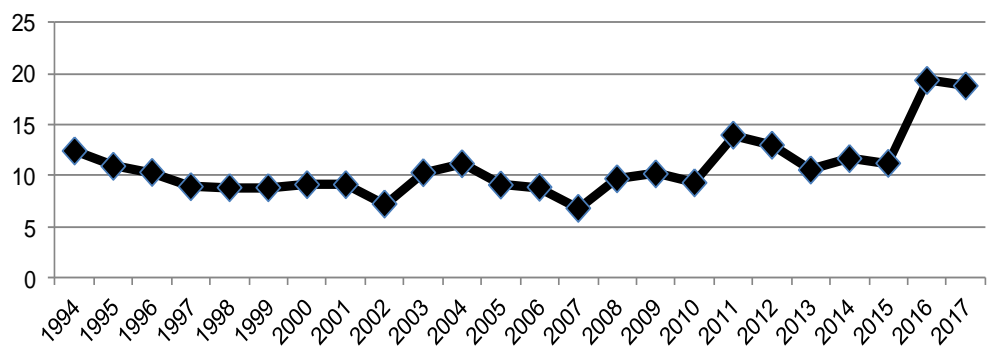

Figure 4. The performance of Egyptian T-bills (91 days)

Source: Central bank of Egypt.

From 1994 to 2017, the higher return of Egyptian T-bills (91 days) is $19.316 \%$ at 2016 but the lower return of Egyptian T-bills (91 days) is $6.781 \%$ at 2007.

Table 3. Descriptive statistics of Egyptian T-bills (91 days)

\begin{tabular}{|c|c|c|c|c|c|c|c|c|}
\hline \multirow{3}{*}{$\begin{array}{l}\text { Egyptian Treasury } \\
\text { bills Return }\end{array}$} & Minimum & Maximum & Mean & Std. Deviation & Skewness & & Kurtosis & \\
\hline & Statistic & Statistic & Statistic & Statistic & Statistic & Std. Error & Statistic & Std. Error \\
\hline & 6.78 & 19.32 & 10.7951 & 3.0373 & 1.711 & 0.472 & 3.176 & 0.918 \\
\hline
\end{tabular}

Source: Statistical Package for the Social Sciences output.

From Table 3, the mean return of return of Egyptian T-bills, it is $10.7951 \%$ but the stander deviation is 3.0373 that show a high level of risk for Egyptian Exchange;

\subsection{Inferential Statistical Methods}

2.5.1 Examine Impact of Inflation and Floating on T-Bills Performance

To measure the significant impact from inflation and Floating on T-bills performance, use regression analysis; Tables (4\&5) show this output.

Table 4. Model summary for T-bills

\begin{tabular}{cccc}
\hline Model Summary & \multicolumn{2}{l}{$\begin{array}{l}\text { Dependent Variable: T-bills Return } \\
\text { Independent Variables: inflation and Floating }\end{array}$} \\
\hline $\mathrm{R}$ & $\mathrm{R}$ Square & Adjusted R Square & Std. Error of the Estimate \\
\hline $0.758452865^{\text {a }}$ & 0.575250749 & 0.534798439 & 2.071596535 \\
\hline
\end{tabular}

a. Predictors: (Constant), USD_R, INFLATIO. 
Table 5. The output of ANOVA test

\begin{tabular}{cccccc}
\hline & Sum of Squares & df & Mean Square & F & Sig. \\
\hline Regression & 122.0546183784 & 2 & 61.02730918921 & 14.22046735826 & .000 \\
Residual & 90.12 & 21 & 4.291512202219 & & \\
Total & 212.17 & 23 & & & \\
\hline
\end{tabular}

Dependent Variable: T-bills Return;

Independent Variables: inflation and Floating.

Table 4 shows the summary of regression test, R-squared is equal to 0.575 This is considered as a high prediction probability level, that's mean that the independent variables can explain about $57.5 \%$ of the change that happens in the return of T-bills; according to ANOVA Test (Table 5) the Independent variables (inflation and Floating) have a significant impact on return of T-bills since that the significant level (1\%) \& Figure 5. Show Normal P-P Plot of Regression Standardized Residual for T-bills, it has a normality pattern.

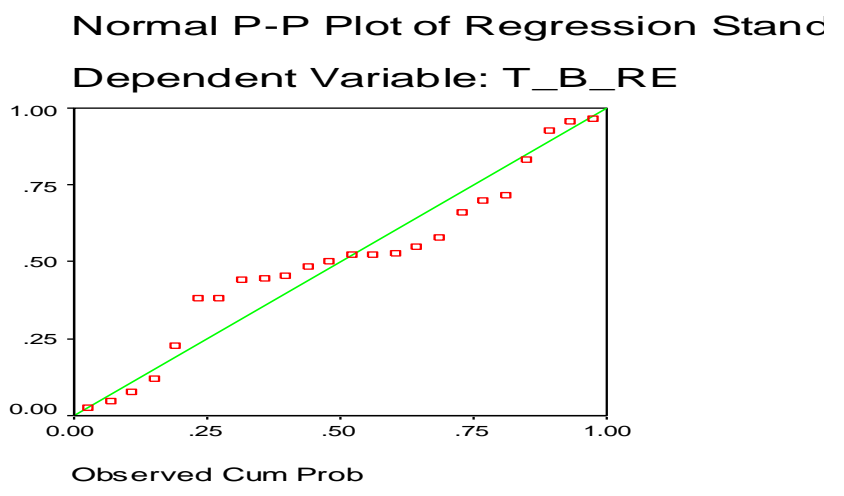

Figure 5. Normal P-P plot of regression standardized residual for T-bills

Source: Statistical Package for the Social Sciences output.

\subsubsection{Examine Impact of Inflation and Floating on Common Stocks Performance}

To measure the significant impact from inflation and Floating on common stocks performance, use regression analysis; tables $(6 \& 7)$ show this output.

Table 6. Model summary for common stocks

\begin{tabular}{cccc}
\hline Model Summary & \multicolumn{4}{l}{$\begin{array}{l}\text { Dependent Variable: common stocks return according to EFG Hermes Index } \\
\text { Independent Variables: inflation and Floating }\end{array}$} \\
\hline $\mathrm{R}$ & $\mathrm{R}$ Square & Adjusted R Square & Std. Error of the Estimate \\
\hline $0.2326243298715^{\mathrm{a}}$ & 0.05411407884818 & -0.03597029459485 & 55.977982238 \\
\hline
\end{tabular}

a. Predictors: (Constant), USD_R, INFLATIO.

Table 6 shows the summary of regression test, R-squared is equal to 0.054 This is considered as a low prediction probability level, that's mean that the independent variables can explain about $5.4 \%$ of the change that happens in the return of common stocks; according to ANOVA Test (Table 7) the Independent variables (inflation and Floating) have a no significant effect on return of common stocks since that the significant level (55.8\%) is higher than 5\% \& Figure 6. Show Normal P-P Plot of Regression Standardized Residual for stocks, it not has a normality pattern.

Table 7. The output of ANOVA test

\begin{tabular}{ccccc}
\hline & Sum of Squares & df & Mean Square & F \\
\hline Regression & 3764.655872682 & 2 & 1882.327936341 & 0.6007043927813 \\
Residual & 65804.22440419 & 21 & 3133.534495437 & 0.5575797517032 \\
Total & 69568.88027687 & 23 & & \\
\hline
\end{tabular}

Dependent Variable: common stocks return according to EFG Hermes Index.

Independent Variables: inflation and Floating. 


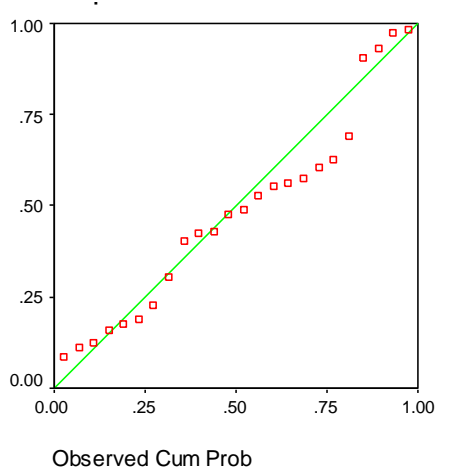

Figure 6. Normal P-P Plot of regression standardized residual for stocks

Source: Statistical Package for the Social Sciences output.

\subsubsection{Comparative Returns between Egyptian T-Bills \& Egyptian Stock}

To measure the significant same returns between Egyptian T-bills \& Egyptian common stock; use Mann-Whitney Test; Table 7 shows this output.

Table 7. Mann-Whitney test for comparative returns

\begin{tabular}{cc}
\hline & RETURN \\
\hline Mann-Whitney U & 219 \\
Wilcoxon W & 495 \\
z & -1 \\
Asymp. Sig. (2-tailed) & 0.318 \\
\hline
\end{tabular}

Source: Statistical Package for the Social Sciences output.

Table 7 shows the summary of Mann-Whitney Test, its significant same average return between common T-bills $\&$ stocks since that the significant level (31.8\%).

\subsubsection{Test of Homogeneity of Variances between Egyptian T-bills \& Egyptian Common Stock}

To measure the significant same Homogeneity of Variances between Egyptian T-bills \& Egyptian common stock; use Levene Statistic; Table 8 shows this output.

Table 8. Test of homogeneity of variances

\begin{tabular}{ccccc}
\hline & Levene Statistic & df1 & df2 & Sig. \\
\hline RETURN & 29.60078151684 & 1 & 44 & .000 \\
\hline
\end{tabular}

Source: Statistical Package for the Social Sciences output.

Levene statistic value is significant, at level of significance 0.05, which indicates that Egyptian T-bills \& stocks variances of return are different.

\subsubsection{Comparative Coefficient of variation between Egyptian T-bills \& Egyptian Stock}

To measure the significant same coefficient of variation between Egyptian T-bills \& Egyptian stock use Mann-Whitney Test; Table 9 shows this output.

Table 9. Mann-Whitney test for comparative coefficient of variation

\begin{tabular}{cc}
\hline & Coefficient of variation \\
\hline Mann-Whitney U & 112 \\
Wilcoxon W & 388 \\
z & -3.35 \\
Asymp. Sig. (2-tailed) & 0.001 \\
\hline
\end{tabular}

Source: Statistical Package for the Social Sciences output. 
Table 9 shows the summary of Mann-Whitney Test, it's not significant same Coefficient of variation between common T-bills \& stocks since that the significant level (1\%).

\section{Conclusion \& Recommendations}

\subsection{Study Conclusion}

Egyptian Exchange is one of the oldest stock markets established in the Middle East its origins go back to 1883 when the Alexandria Stock Exchange was established, followed by Cairo Stock Exchange in 1903, in 1994 Egyptian Exchange returned to active their role in Egyptian economy, this study concluded that there is an impact of Inflation and Floating exchange rate on return of Egyptian T-bills, but didn't find this impact on return of Egyptian common stock; but when making a Comparative performance between Egyptian T-bills \& common stock, the study found the same average return but a different variance of their return \& the Coefficient of variation; This is due to the crowding out effect of government financial instruments to private sector's, which reflects financing budget deficit at the expense of financing economic development processes.

Thus, this study has the same results for Egyptian T-bills against inflation as many Previous studies; but it has different results for Egyptian common stocks performance under inflation with results at Italy (Bagliano \& Beltratti, 1997); Pakistan (Akmal, 2007) USA (Ang et al., 2012) \& in addition, this study has a same different when Comparative returns between Egyptian T-bills \& Egyptian stock with results at Ghana (Antwi et al., 2012); In addition \& for Egyptian common stocks, this study pointed to the impact of exchange rate Floating on short-run international capital movements (SICM), which is consistent with the study results of (Li, Chang, \& Ma, 2018), finally, the study found a preference for investing in Egyptian Treasury bills relative to Egyptian common stocks in the long term, which is Indirect consistent with (Bessembinder, 2017).

\subsection{Study Recommendations}

Egyptian financial institutions have a higher weight of government debt instruments in their investment; so; Providing a development scenario for the legislative framework through the Central Bank of Egypt \& Financial Supervisory Authority (Egypt) to determine the maximum limits of investment at government debt instruments, while providing a supportive policy for the entry of financial institutions in financing development projects; In this regard, we propose the use of non-monetary tools such as reserve components and capital parameter components for Egyptian banks, Mutual funds, pensions and insurance companies.

\section{References}

Akmal, M. S. (2007). Stock returns and inflation: An ARDL econometric investigation utilizing Pakistani data. Pakistan Economic and Social Review, 45(1), 89-105. Retrieved from http://www.jstor.org/stable/25825305

Aktürk, H. (2016). Do stock returns provide a good hedge against inflation? An empirical assessment using Turkish data during periods of structural change. International Review of Economics \& Finance, 45, 230-246. https://doi.org/10.1016/j.iref.2016.06.002

Ang, A., Brière, M., \& Signori, O. (2012). Inflation and individual equities. Financial Analysts Journal, 68(4), 36-55. https://doi.org/10.2469/faj.v68.n4.3

Antwi, S., Mills, A. E. F. E., Mills, A. G., \& Zhao, X. (2012). An Empirical Analysis of the Performance of the Ghana Stock Exchange and Treasury Bills. International Journal of Business and Social Science, 3(23), 97-108. Retrieved from https://papers.ssrn.com/sol3/papers.cfm?abstract_id=2361002

Bagliano, F. C., \& Beltratti, A. (1997). Stock returns, the interest rate and inflation in the Italian stock market: A long-run perspective. Giornale degli Economisti e Annali di Economia, 139-167. Retrieved from http://www.jstor.org/stable/23248314

Bampinas, G., \& Panagiotidis, T. (2016). Hedging inflation with individual US stocks: A long-run portfolio analysis. The North American Journal of Economics and Finance, 37, 374-392. https://doi.org/10.1016/j.najef.2016.05.007

Bessembinder, H. (2017). Do Stocks Outperform Treasury Bills? Work paper Available at SSRN. Journal of Financial Economics (JFE), Forthcoming. https://doi.org/10.2139/ssrn.2900447

Fama, E. F. (1981). Stock returns, real activity, inflation, and money. The American Economic Review, 71(4), 545-565. Retrieved from http://www.jstor.org/stable/1806180

Jacoby, G., Fowler, D. J., \& Gottesman, A. A. (2000). The capital asset pricing model and the liquidity effect: A theoretical approach. Journal of Financial Markets, $3(1), \quad 69-81$. https://doi.org/10.1016/S1386-4181(99)00013-0 
Kanas, A., \& Karkalakos, S. (2017). Equity flows, stock returns and exchange rates. International Journal of Finance \& Economics, 22(2), 159-168. https://doi.org/10.1002/ijfe.1574

Khan, K. N. (2004). Inflation and stock market performance: A case study for Pakistan. Savings and Development, 28(1), 87-101. Retrieved from http://www.jstor.org/stable/25830851

Li, X., Su, C. W., Chang, H. L., \& Ma, J. (2018). Do short-term international capital movements play a role in exchange rate and stock price transmission mechanism in China? International Review of Economics \& Finance. https://doi.org/10.1016/j.iref.2018.02.010

Lintner, J. (1965). Security prices, risk, and maximal gains from diversification. The Journal of Finance, 20(4), 587-615. https://doi.org/10.1111/j.1540-6261.1965.tb02930.x

Markowitz, H. (1952). Portfolio selection. The Journal of Finance, 7(1), 77-91. https://doi.org/10.1111/j.1540-6261.1952.tb01525.x

Mossin, J. (1966). Equilibrium in a capital asset market. Econometrica: Journal of the Econometric Society, 34(4), 768-783. Retrieved from http://www.jstor.org/stable/1910098

Otieno, D. A., Ngugi, R. W., \& Muriu, P. W. (2018). The impact of inflation rate on stock market returns: Evidence from Kenya. Journal of Economics and Finance, 1-18. https://doi.org/10.1007/s12197-018-9430-5

Perold, A. F. (2004). The capital asset pricing model. Journal of Economic Perspectives, 18(3), 3-24. https://doi.org/10.1257/0895330042162340

Rambaud, S. C., Pérez, J. G., Granero, M. A. S., \& Segovia, J. E. T. (2005). Theory of portfolios: New considerations on classic models and the Capital Market Line. European Journal of Operational Research, 163(1), 276-283. https://doi.org/10.1016/j.ejor.2004.01.016

Ross, S. A. (1976). The arbitrage theory of capital asset pricing. Journal of Economic Theory, 13(3), 341-360. https://doi.org/10.1016/0022-0531(76)90046-6

Sharpe, W. F. (1964). Capital asset prices: A theory of market equilibrium under conditions of risk. The Journal of Finance, 19(3), 425-442. https://doi.org/10.1111/j.1540-6261.1964.tb02865.x

Suhaibu, I., Harvey, S. K., \& Amidu, M. (2017). The impact of monetary policy on stock market performance: Evidence from twelve (12) African countries. Research in International Business and Finance, 42, 1372-1382. https://doi.org/10.1016/j.ribaf.2017.07.075

Tiwari, A. K., Dar, A. B., Bhanja, N., Arouri, M., \& Teulon, F. (2015). Stock returns and inflation in Pakistan. Economic Modelling, 47, 23-31. https://doi.org/10.1016/j.econmod.2014.12.043

Zabarankin, M., Pavlikov, K., \& Uryasev, S. (2014). Capital asset pricing model (CAPM) with drawdown measure. European Journal of Operational Research, 234(2), 508-517. https://doi.org/10.1016/j.ejor.2013.03.024

\section{Appendix A}

Statistical Package for the Social Sciences output

Descriptives

Descriptive Statistics

\begin{tabular}{|l|r|c|c|c|c|c|c|r|r|}
\hline & $\mathrm{N}$ & Minimum & Maximum & Mean & \multicolumn{1}{c|}{ Std. } & \multicolumn{2}{c|}{ Skewness } & \multicolumn{2}{c|}{ Kurtosis } \\
\cline { 2 - 9 } & Statistic & Statistic & Statistic & Statistic & Statistic & Statistic & Std. Error & Statistic & Std. Error \\
\hline $\begin{array}{l}\text { INFLATIO } \\
\begin{array}{l}\text { Valid N } \\
\text { (listwise) }\end{array}\end{array}$ & 24 & 2.23 & 29.73 & 9.4494 & 6.3903 & 1.691 & .472 & 3.518 & .918 \\
\hline
\end{tabular}

Descriptives

De scriptive Statistics

\begin{tabular}{|c|c|c|c|c|c|c|c|c|c|}
\hline & $\mathrm{N}$ & Minimum & Maximum & Mean & Std. & \multicolumn{2}{|c|}{ Skewness } & \multicolumn{2}{|c|}{ Kurtosis } \\
\hline & Statistic & Statistic & Statistic & Statistic & Statistic & Statistic & Std. Error & Statistic & Std. Error \\
\hline $\begin{array}{l}\text { STOCK_RE } \\
\text { Valid N } \\
\text { (listwise) }\end{array}$ & $\begin{array}{l}24 \\
24\end{array}$ & -53.94 & 141.95 & 27.7584 & 54.9976 & .582 & .472 & -.259 & .918 \\
\hline
\end{tabular}


Descriptives

Descriptive Statistics

\begin{tabular}{|l|r|r|r|r|r|r|r|r|r|}
\hline & \multicolumn{1}{|c|}{$\mathrm{N}$} & \multicolumn{1}{c|}{ Minimum } & Maximum & \multicolumn{1}{c|}{ Mean } & \multicolumn{1}{c|}{ Std. } & \multicolumn{2}{c|}{ Skewness } & \multicolumn{2}{c|}{ Kurtosis } \\
\cline { 2 - 9 } & Statistic & Statistic & Statistic & Statistic & Statistic & Statistic & Std. Error & Statistic & Std. Error \\
\hline $\begin{array}{l}\text { T_B_RE } \\
\text { Valid N } \\
\text { (listwise) }\end{array}$ & 24 & 6.78 & 19.32 & 10.7951 & 3.0373 & 1.711 & .472 & 3.176 & .918 \\
\hline
\end{tabular}

Descriptives

De scriptive Statistics

\begin{tabular}{|l|r|r|r|r|r|r|r|r|r|}
\hline & \multicolumn{1}{|c|}{$\mathrm{N}$} & Minimum & Maximum & \multicolumn{1}{c|}{ Mean } & \multicolumn{1}{c|}{ Std. } & \multicolumn{2}{c|}{ Skewness } & \multicolumn{2}{c|}{ Kurtosis } \\
\cline { 2 - 8 } & Statistic & Statistic & Statistic & Statistic & Statistic & Statistic & Std. Error & Statistic & Std. Error \\
\hline USD_R & 24 & -4.49 & 136.35 & 9.4013 & 27.9223 & 4.431 & .472 & 20.712 & .918 \\
$\begin{array}{l}\text { Valid N } \\
\text { (listwise) }\end{array}$ & 24 & & & & & & & & \\
\hline
\end{tabular}

Regression

Variables Ente red/Removel

\begin{tabular}{|l|c|c|l|}
\hline Model & $\begin{array}{c}\text { Variables } \\
\text { Entered }\end{array}$ & $\begin{array}{c}\text { Variables } \\
\text { Removed }\end{array}$ & Method \\
\hline 1 & INFLATIO $^{\mathrm{a}}$ & & Enter \\
\hline
\end{tabular}

a. All requested variables entered.

b. Dependent Variable: T_B_RE

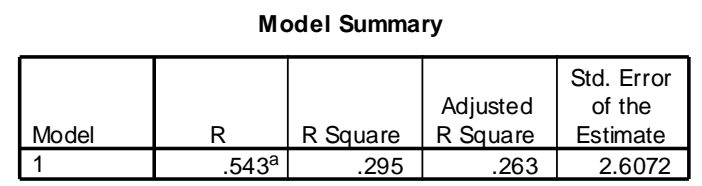

a. Predictors: (Constant), INFLATIO

ANOVA

\begin{tabular}{|c|c|c|c|c|c|c|}
\hline Model & & $\begin{array}{l}\text { Sum of } \\
\text { Squares }\end{array}$ & df & $\begin{array}{c}\text { Mean } \\
\text { Square }\end{array}$ & $F$ & Sig. \\
\hline \multirow[t]{3}{*}{1} & Regression & 62.628 & 1 & 62.628 & 9.213 & $.006^{\mathrm{a}}$ \\
\hline & Residual & 149.548 & 22 & 6.798 & & \\
\hline & Total & 212.176 & 23 & & & \\
\hline
\end{tabular}

a. Predictors: (Constant), INFLATIO

b. Dependent Variable: T_B_RE

Coefficients

\begin{tabular}{|c|c|c|c|c|c|c|}
\hline \multirow[b]{2}{*}{ Model } & & \multicolumn{2}{|c|}{$\begin{array}{c}\text { Unstandardized } \\
\text { Coefficients }\end{array}$} & \multirow{2}{*}{$\begin{array}{c}\begin{array}{c}\text { Standardi } \\
\text { zed } \\
\text { Coefficien } \\
\text { ts }\end{array} \\
\text { Beta } \\
\end{array}$} & \multirow[b]{2}{*}{$\mathrm{t}$} & \multirow[b]{2}{*}{ Sig. } \\
\hline & & $\mathrm{B}$ & Std. Error & & & \\
\hline & (Constant) & 8.355 & .964 & & 8.666 & .000 \\
\hline & INFLATIO & .258 & .085 & .543 & 3.035 & .006 \\
\hline
\end{tabular}

a. Dependent Variable: T_B_RE

Regression

Variables Entered/Removel

\begin{tabular}{|l|l|l|l|}
\hline Model & $\begin{array}{c}\text { Variables } \\
\text { Entered }\end{array}$ & $\begin{array}{c}\text { Variables } \\
\text { Removed }\end{array}$ & Method \\
\hline 1 & $\begin{array}{l}\text { USD_R, } \\
\text { INFLATIO }\end{array}$ &. & Enter \\
\hline
\end{tabular}

a. All requested variables entered.

b. Dependent Variable: T_B_RE

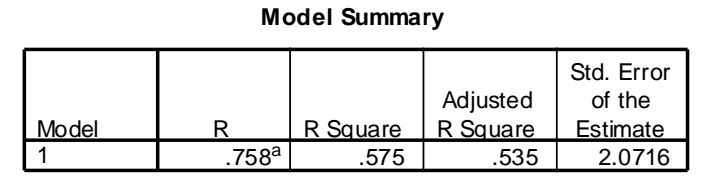

a. Predictors: (Constant), USD_R, INFLATIO

ANOVA

\begin{tabular}{|ll|r|r|r|r|c|}
\hline Model & & \multicolumn{1}{|c|}{$\begin{array}{c}\text { Sum of } \\
\text { Squares }\end{array}$} & \multicolumn{1}{c|}{ df } & \multicolumn{1}{c|}{$\begin{array}{c}\text { Sean } \\
\text { Square }\end{array}$} & \multicolumn{1}{c|}{ F } & Sig. \\
\hline 1 & Regression & 122.055 & 2 & 61.027 & 14.220 & $.000^{\text {a }}$ \\
& Residual & 90.122 & 21 & 4.292 & & \\
& Total & 212.176 & 23 & & & \\
\hline
\end{tabular}

a. Predictors: (Constant), USD_R, INFLATIO

b. Dependent Variable: T_B_RE 


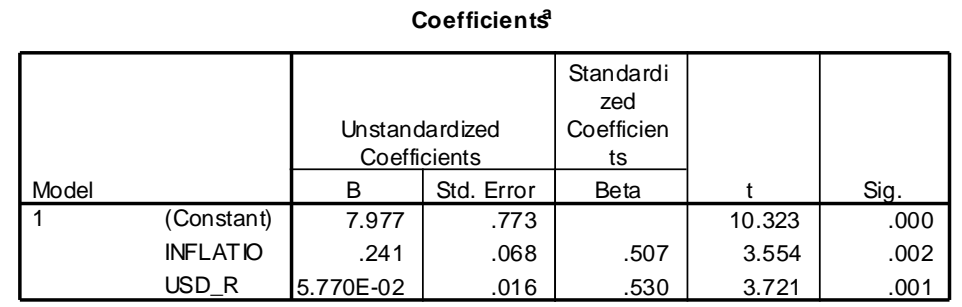

a. Dependent Variable: T_B_RE

Regression

Variables Entered/Removel

\begin{tabular}{|l|l|l|l|}
\hline Model & $\begin{array}{c}\text { Variables } \\
\text { Entered }\end{array}$ & $\begin{array}{c}\text { Variables } \\
\text { Removed }\end{array}$ & Method \\
\hline 1 & $\begin{array}{l}\text { USD_R, } \\
\text { INFLATIO }\end{array}$ & & Enter \\
\hline
\end{tabular}

a. All requested variables entered.

b. Dependent Variable:STOCK_RE

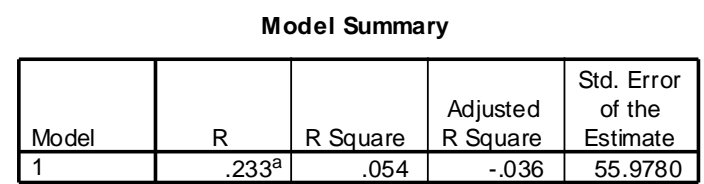

a. Predictors: (Constant), USD_R, INFLATIO

ANOVA ${ }^{b}$

\begin{tabular}{|ll|c|r|c|c|c|}
\hline Model & & $\begin{array}{c}\text { Sum of } \\
\text { Squares }\end{array}$ & df & $\begin{array}{c}\text { Mean } \\
\text { Square }\end{array}$ & F & Sig. \\
\hline 1 & Regression & 3764.656 & 2 & 1882.328 & .601 & $.558^{\mathrm{a}}$ \\
& Residual & 65804.224 & 21 & 3133.534 & & \\
& Total & 69568.880 & 23 & & & \\
\hline
\end{tabular}

a. Predictors: (Constant), USD_R, INFLATIO

b. Dependent Variable: STOCK_RE

Coefficients

\begin{tabular}{|c|c|c|c|c|c|c|}
\hline \multirow{2}{*}{\multicolumn{2}{|c|}{ Model }} & \multicolumn{2}{|c|}{$\begin{array}{l}\text { Unstandardized } \\
\text { Coefficients }\end{array}$} & \multirow{2}{*}{$\begin{array}{c}\text { Standardi } \\
\text { zed } \\
\text { Coefficien } \\
\text { ts }\end{array}$} & \multirow[b]{2}{*}{$t$} & \multirow[b]{2}{*}{ Sig. } \\
\hline & & $\mathrm{B}$ & Std. Error & & & \\
\hline & (Constant) & 22.496 & 20.881 & & 1.077 & .294 \\
\hline & INFLATIO & .103 & 1.831 & .012 & .056 & .956 \\
\hline & USD_R & .456 & .419 & .231 & 1.088 & .289 \\
\hline
\end{tabular}

a. Dependent Variable: STOCK_RE

Charts

Normal P-P Plot of Regression Stand

Dependent Variable: T_B_RE

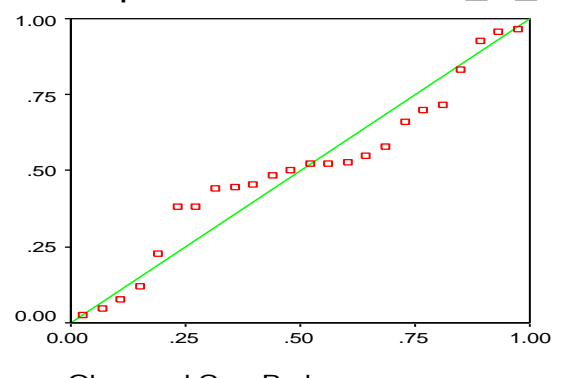

Observed Cum Prob

\section{Scatterplot}

Dependent Variable: T_B_RE

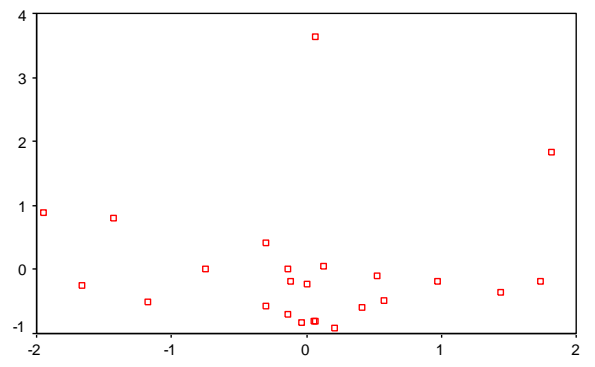

Regression Standardized Residual 
Charts

Normal P-P Plot of Regression St

Dependent Variable: STOCK_RE

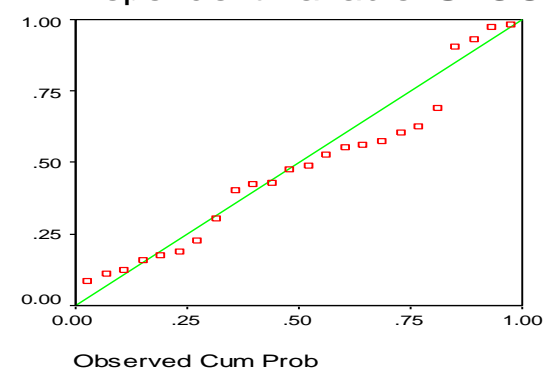

NPar Tests

Mann-Whitney Test

Ranks

\begin{tabular}{|rl|r|r|r|}
\hline & TYPES & $\mathrm{N}$ & $\begin{array}{c}\text { Mean } \\
\text { Rank }\end{array}$ & $\begin{array}{c}\text { Sum of } \\
\text { Ranks }\end{array}$ \\
\hline RETURN & 1.00 & 23 & 25.48 & 586.00 \\
& 2.00 & 23 & 21.52 & 495.00 \\
& Total & 46 & & \\
\hline
\end{tabular}

Scatterplot

Dependent Variable: STOCK_RE

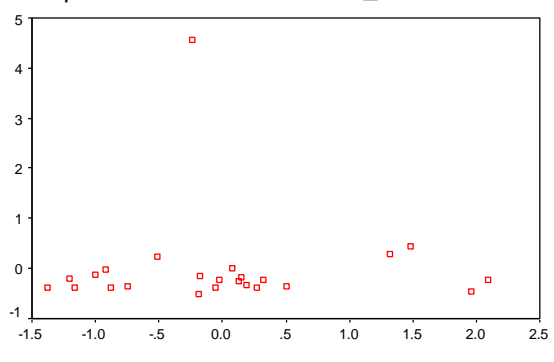

Regression Standardized Residual

NPar Tests

Mann-Whitney Test

\begin{tabular}{|rl|r|r|c|}
\hline & Ranks \\
\hline & TYPES & \multicolumn{1}{|c|}{$\mathrm{N}$} & $\begin{array}{c}\text { Mean } \\
\text { Rank }\end{array}$ & $\begin{array}{c}\text { Sum of } \\
\text { Ranks }\end{array}$ \\
\hline CV & 1.00 & 23 & 30.13 & 693.00 \\
& 2.00 & 23 & 16.87 & 388.00 \\
& Total & 46 & & \\
\hline
\end{tabular}

Te st Statistics

\begin{tabular}{|l|r|}
\hline & RETURN \\
\hline Mann-Whitney & 219.000 \\
U & 495.000 \\
Wilcoxon W & -1.000 \\
$Z$ & .318 \\
$\begin{array}{l}\text { Asymp. Sig. } \\
\text { (2-tailed) }\end{array}$ & \\
\hline
\end{tabular}

a. Grouping Variable: TYPES

\section{Te st Statistics}

\begin{tabular}{|l|r|}
\hline & \multicolumn{1}{|c|}{ CV } \\
\hline Mann-Whitney & 112.000 \\
U & 388.000 \\
Wilcoxon W & -3.350 \\
Z & .001 \\
Asymp. Sig. & \\
(2-tailed) & \\
\hline
\end{tabular}

a. Grouping Variable: TYPES

Oneway

\begin{tabular}{|c|c|c|c|c|}
\hline & $\begin{array}{l}\text { Levene } \\
\text { Statistic }\end{array}$ & df1 & df2 & Sig. \\
\hline$\overline{\text { RETURN }}$ & 29.601 & 1 & 44 & .000 \\
\hline
\end{tabular}

ANOVA

\begin{tabular}{|c|c|c|c|c|c|c|}
\hline & & $\begin{array}{c}\text { Sum of } \\
\text { Squares }\end{array}$ & df & $\begin{array}{c}\text { Mean } \\
\text { Square }\end{array}$ & $\mathrm{F}$ & Sig. \\
\hline \multirow[t]{3}{*}{ RETURN } & $\begin{array}{l}\text { Between } \\
\text { Groups }\end{array}$ & & 1 & \multirow{3}{*}{$\begin{array}{r}2393.126 \\
579.252\end{array}$} & \multirow[t]{3}{*}{4.131} & \multirow[t]{3}{*}{.048} \\
\hline & $\begin{array}{l}\text { Within } \\
\text { Groups }\end{array}$ & 25487.070 & 44 & & & \\
\hline & Total & 27880.196 & 45 & & & \\
\hline
\end{tabular}




\section{Appendix B}

EFG Hermes Index Components:

- Abu Dhabi Islamic Bank- Egypt (ADIB)

- Alexandria Spinning \& Weaving (SPIN)

- Arab Cotton Ginning (ACGC)

- Asek Company for Mining - Ascom (ASCM)

- Canal Shipping Agencies (CSAG)

- Citadel Capital - Common Shares (CCAP)

- Eastern Tobacco (EAST)

- Egyptian Financial \& Industrial (EFIC)

- Egyptian Iron \& Steel (IRON)

- Egyptian Media Production City (MPRC)

- EL Ezz Aldekhela Steel - Alexandria (IRAX)

- El Kahera Housing (ELKA)

- El Nasr Clothing \& Textiles (KABO)

- El Saeed Contracting \& Real Estate Investment (UEGC)

- Electro Cable Egypt (ELEC)

- GB AUTO (AUTO)

- Heliopolis Housing (HELI)

- Naeem Holding (NAHO)

- Qatar Natl Bank (QNBA)

- Remco Touristic Villages Constr (RTVC)

- Sinai Cement (SCEM)

- Six of October Development \& Invest (OCDI)

- Suez Canal Bank (CANA)

- United Arab Shipping (UASG)

\section{Copyrights}

Copyright for this article is retained by the author(s), with first publication rights granted to the journal.

This is an open-access article distributed under the terms and conditions of the Creative Commons Attribution license (http://creativecommons.org/licenses/by/4.0/). 